\title{
Molecular stability of a vaccine strain of Canine coronavirus after serial passages in A72 cells
}

\section{Estabilidade molecular de uma amostras vacinal de Coronavírus canino após passagens seriadas em células A72}

\author{
Iracema Nunes de BARROS ${ }^{1,2}$; Sheila Oliveira de Souza SILVA ${ }^{1,2}$; Sueli Akemi TANIWAKI ${ }^{1,2}$; \\ Paulo Eduardo BRANDÃO ${ }^{1,2}$ \\ ${ }^{1}$ Universidade de São Paulo, Faculdade de Medicina Veterinária e Zootecnia, Departamento de Medicina Veterinária Preventiva \\ e Saúde Animal, São Paulo - SP, Brazil \\ ${ }^{2}$ Universidade de São Paulo, Coronavirus Research Group, São Paulo - SP, Brazil
}

\begin{abstract}
Canine coronavirus (CCoV) exists in types I and II and infects dogs leading mainly to enteritis, though type II has already been associated with generalized and highly lethal infection. A CCoV-type II inactivated vaccine produced in A72 canine cells is available worldwide and largely used, though the molecular stability after serial passages of vaccine seeds is unknown. This article reports the evolution of the CCoV-II vaccine strain 1-71 in A72 cells based on partial $S$ gene sequencing, showing the predominance of neutral evolution and the occurrence of four sites under purifying selection. Thus, cell-adapted strains of CCoV-II may be genetically stable after serial passages in a same cell line due to a stable virus-host relationship.
\end{abstract}

Keywords: Canine coronavirus. Vaccine. Passages. Evolution. A72 cells.

\section{Resumo}

O Coronavírus canino (CCoV) ocorre como tipos I e II e infecta cães, levando principalmente a enterite, apesar do tipo II já ter sido associado à infecção generalizada e altamente letal. Uma vacina de CCoV-II inativada produzida em células caninas A72 é disponível mundialmente e largamente utilizada, apesar da sua estabilidade molecular após passagens seriadas de sementes vacinais ser desconhecida. Este artigo relata a evolução da amostra vacinal CCoC-II 1-71 em células A-72 com base em sequenciamento parcial do gene $S$, demonstrando predomínio de evolução neutra e a ocorrência de quaro sítios sob seleção purificante. Portanto, amostras de CCoV-II adaptadas a cultivos celulares podem ser estáveis geneticamente após passagens seriadas em uma mesma linhagem celular devido à existência de uma relação estável vírus-hospedeiro.

Palavras-chave: Coronavírus canino. Vacina. Passagens. Evolução. Células A-72.

Correspondence to:

Iracema Nunes de Barros

Universidade de São Paulo, Faculdade de Medicina Veterinária

e Zootecnia, Departamento de Medicina Veterinária

Preventiva e Saúde Animal

Av. Prof. Dr. Orlando Marques de Paiva, 87

CEP 05508-270, São Paulo, SP, Brazil

E-mail: cemavet@usp.br

Received: 24/02/2016

Approved: 12/01/2017

\section{Introduction}

Canine coronavirus $(\mathrm{CCoV})$, feline coronavirus (FCoV), and transmissible gastroenteritis virus (TGEV) are currently classified in the same species Alphacoronavirus-1,
(Nidovirales: Coronaviridae: Coronavirinae) (DE GROOT et al., 2013) and evolutionary studies on Alphacoronavirus-1 have demonstrated that some geno-/serotypes of these viruses emerged as a result of recombination events between each other (PRATELLI et al., 2004; PRATELLI, 2006; DECARO et al., 2009).

$\mathrm{CCoV}$ presents an enveloped pleomorphic virion of $220 \mathrm{~nm}$ in diameter and a single-stranded positive-sense RNA genome of circa $29 \mathrm{~kb}$ consisting of genes encoding the spike (S) envelope glycoprotein, nucleocapsid (N), membrane (M), and envelope (E) structural proteins and ORFs translated into non structural proteins, as replicase polyprotein (ORF1), 3a, 3b, 3c, 7a, and 7b (MASTERS; PERLMAN, 2013). 
The S protein is the main target of neutralizing antibodies and the most polymorphic protein in coronaviruses. It occurs as trimmers, with a highly variable ectodomain (subunit S1) and a more stable endodomain (S2 subunit) involved in membrane fusion (BOSCH et al., 2003; MASTERS, 2006).

Estimates on the time of the most recent common ancestor (tMRCA) place the origin of Alphacoronaviruses 293 million of years ago and, due to the proofreading activity of the NSP14 of coronaviruses, these viruses show a number of mutations per site per replication up to E-5, which is quite similar to the one found in DNA viruses (WERTHEIM et al., 2013).

In spite of the large use of cell-passaged $\mathrm{CCoV}$ vaccine seeds for years on and the use of high-passage of vaccine strains in vaccine trials (PRATELLI, 2007), no data on the molecular diversity and the mechanisms of molecular evolution of $\mathrm{CCoV}$ in vitro is available. This knowledge is paramount for the understanding of the genetic stability of vaccine seeds and might also help shed some light on basic mechanisms of coronavirus molecular evolution.

The aim of this investigation was to assess the clonal diversity of a CCoV-II vaccine strain after serial passages in A-72 cells based on the molecular diversity of the S2 subunit of the spike gene and the selection regime driving $\mathrm{CCoV}$ in vitro evolution.

\section{Material and Methods}

\section{CCoV strain and cell line}

CCoV 1-71 type II vaccine strain (ATCC VR 809, $10^{4.03} \mathrm{TCID}_{50} / \mathrm{mL}$ ) and canine fibroma A72 (ATCC CRL 1542) cell line were used for this study and were kindly provided by Biovet Laboratories, Brazil.

Cells were propagated in Eagle's MEM supplemented with $10 \%$ fetal bovine serum (FBS) and 25mM HEPES (4-(2-hydroxyethyl)-1-piperazineethanesulfonic acid).

\section{Serial passages in A72}

For the first passage, $1 \mathrm{~mL}$ of CCV 1-71 strain diluted 1:10 (v/v) in Eagle's MEM was inoculated in $25 \mathrm{~cm}^{2}$ flasks containing partially $(\sim 70 \%)$ confluent A72 cells and incubated at $37^{\circ} \mathrm{C} / 1$ hour for virus attachment. Next, the virus suspension was discarded and $7 \mathrm{ml}$ of Eagle's MEM supplemented with $2 \%$ FBS was added to the flask.

Cells were daily observed with a light microscope for cytopathic effect (CPE) for five days. After this observation period, the monolayers were frozen at $-80^{\circ} \mathrm{C}$ regardless of the presence of CPE. Then, $1 \mathrm{~mL}$ was used in the next passage following the same protocol described above up to the $9^{\text {th }}$ passage

For each passage, a $25 \mathrm{~cm}^{2}$ with A72 cell was mockinfected (negative control) with Eagle's MEM without virus under the same conditions described for virus inoculation.

\section{RT-PCR for partial S gene amplification}

For the original CCoV 1-71 and each passage (CCoV and negative control), total RNA was extracted with TRIzol Reagent $^{\text {TM }}$ (Life Technologies) following the manufacturer's instructions. cDNA synthesis was carried out with Random Primers $^{\mathrm{TM}}$ (Life Technologies ) and M-MLV Reverse Transcriptase $^{\mathrm{rm}}$ (Life Technologies) accordingly to the manufacturer's instructions.

For partial $S$ gene amplification, the primers described by Pratelli et al. (PRATELLI et al., 2004) (S 5'TGCATTTGTGTCTCAGACTT3'/ S6 5'CCAAGGCCATTTTACATAAG3', nt 3492 to 4185 of $\mathrm{S}$ gene, $\mathrm{S} 2$ subunit in the reference strain $\mathrm{CCoV}$ 1-71 GenBank JQ404409) were used with Platinum Taq Polymerase High Fidelity $^{\mathrm{TM}}$ (Life Technologies) following the manufacturer's instructions.

\section{DNA cloning and Sequencing}

The 694 bp amplicons were purified using ExoSAPIT $^{\mathrm{TM}}$ (Affymetrix) and the total DNA quantified with Low Mass DNA Ladder ${ }^{\mathrm{rm}}$ (Life Technologies) according to the manufacturer's instructions.

The purified amplicons were inserted into the plasmid vector pTZ57R/ $/ \mathrm{T}^{\mathrm{TM}}$ (InsTAclone) in an insert: vector proportion of 3:1 and the ligation reaction was performed at $15^{\circ} \mathrm{C}$ for 16 hours, followed by the addition of $5 \mu \mathrm{L}$ of ligation reaction to $100 \mu \mathrm{L}$ of competent DH5 $\alpha$ E. coli cells grown in LB (LuriaBertani) liquid medium and incubated on ice from 20 to 30 min. After a thermal shock $\left(42^{\circ} \mathrm{C} / 2 \mathrm{~min}\right.$ and ice $\left./ 2 \mathrm{~min}\right), 900 \mu \mathrm{L}$ of LB medium without antibiotics were added to the reaction and incubated at $37^{\circ} \mathrm{C} / 150 \mathrm{rpm} / 1 \mathrm{~h} 30 \mathrm{~min}$.

The cells were then plated on solid LB medium containing $100 \mu \mathrm{g} / \mathrm{ml}$ ampicillin, IPTG (5-bromo-4-chloro3 -indolyl- $\beta$-D-galactosidase), and X-Gal (isopropylthio- $\beta$ Dgalactoside), and then incubated for 16 hours at $37^{\circ} \mathrm{C}$.

Individual white colonies, predicted to have inserts, were selected and subjected to a PCR reaction to confirm the insertion using GoTaq Green Master $\mathrm{Mix}^{\mathrm{TM}}$ (Promega) accordingly to the manufacturer's 
instructions and the plasmid-targeting primers M13F 5'GTTTTCCCAGTCACGAC3\% M13 5'CAGGAAACAGCTATGAC 3').

A number from 9 to 13 clones for each passage and of the original virus confirmed as carrying the inserted amplicon were subjected to DNA sequencing with BigDye $3.1^{\mathrm{TM}}$ (Applied Byosystems) and ABI-3500 Genetic Analyzer ${ }^{\mathrm{TM}}$ (Applied Byosystems) as per manufacturer's instructions, using primers M13F and M13R. Evaluation of the quality of chromatograms obtained for each DNA strand sequences was performed using Phred application online (http://asparagin. cenargen.embrapa.br/phph/) and manual checked using the program Finch TV ( ${ }^{\circ}$ Geospiza) to search for interpretation errors and discrepancies between each DNA strand sequenced. The final sequence of each clone was obtained using Cap-Contig, with PHRED score $>20$, in the program Bioedit version 7.2.5 and submitted to BLASTn in http:// www.ncbi.nlm.nih.gov/BLAST for homology checking.

\section{Mutation analysis}

The occurrence of recombination was assessed with RDP, GENECONV, Bootscan, MaxiChi, Chimaera, SiScan, and 3Seq methods with Bonferroni correction and highest acceptable P-value of 0.05 using RDP $4 \beta 36$ (MARTIN et al., 2010).

Sequences of clones of each passage and the original virus (e.g. intra-passage analysis) were aligned using Clustal/W in Bioedit version 7.2.5 and compared in terms of nucleotide and amino acid identities. Identical sequences that predominated in the intra-passage comparison were named as Master Sequence for that passage, while those in lower frequencies were named Variants.

Next, the Variants and Master Sequences for all passages and the original virus were aligned together including Alphacoronavirus homologous sequences retrieved from GenBank (JQ404409; JF682842; GQ477367; KC175340; JQ404410; EU924790; AY342160; D13096; EU924791; EU856361; EU856362; DQ201447; HQ462571; GQ152141;
NC_002306; DQ811789; DQ112226) using CLUSTAL/W running in Bioedit 7.2.5.

All sequences generated in this study were deposited in the GenBank under the accession numbers: KP281485 to KP281596.

\section{Selection regime analysis}

For each codon, estimates of the numbers of inferred synonymous (s) and nonsynonymous ( $\mathrm{n}$ ) substitutions and the numbers of sites that are estimated to be synonymous (S) and nonsyonymous (N) were produced using the joint Maximum Likelihood (ML) reconstructions of ancestral states under a Muse-Gaut model (MUSE; GAUT, 1994) of codon substitution and General Time Reversible model of nucleotide substitution. For estimating ML values, a tree topology was automatically computed. The test statistic $\mathrm{dN}$ - dS was used for detecting codons that have undergone positive selection, where $\mathrm{dS}$ is the number of synonymous substitutions per site and $\mathrm{dN}$ is the number of nonsynonymous substitutions per site. Values of $p$ less than 0.05 were considered significant at a $5 \%$ level. These analyses were conducted using HyPhy software v. 2.2.1 (POND et al., 2005) implemented in MEGA6 (TAMURA et al., 2013).

\section{Results}

\section{Mutation analysis}

A total of 112 viable DNA sequences were obtained from passages 1 to 9 and from the original CCoV 1-71 strain, with a number of clones per passage ranging from 9 to 13 and only 12 nucleotide mutations found amongst these sequences, ranging from 0 to 3 per passage (Table 1 ) but in a passage-exclusive way. No recombination was found amongst these sequences.

From these mutations, five were silent transitions (A3519G, T3813C, C3699T, T4155C, and A3527G); 
three were missense transitions (A3817G, G3868A, and G3875A), one silent transversion (A4165C) and two missense transversions (G3528T and T3803G).

Besides, a deletion (TTGATATTA/ Ile/Asp/Ile, nucleotides 3935 to 3943 ) was found in one out of 11 clones of passage 3 .

\section{Selection regime analysis}

None of the 12 sites with mutations (Table 1) was under positive selection and only sites A3519G, T3813C, C3699T, and T4155C were found to be under purifying selection, while the remaining eight mutations were neutral, including the deletion.

Table 1 - Nucleotide and putative amino acids mutations of the spike gene of CCoV stain 1-71 passaged in A72 cells. P- passage number ( 0 refers to the original virus); $\mathrm{NC}$ - number of clones sequenced per each passage; $\mathrm{M} / \mathrm{P}$ - number of mutations per passage regarding the Master Sequence. Numbers in cells of each mutation represent the number of occurrences of that specific mutation. Positions at S gene in the reference strain 1-71 GenBank JQ404409 - São Paulo - 2015

\begin{tabular}{|c|c|c|c|c|c|c|c|c|c|c|c|c|c|c|}
\hline $\mathbf{P}$ & NC & $M / P$ & $\begin{array}{l}\text { A3519G } \\
\text { Arg/Arg }\end{array}$ & $\begin{array}{l}\text { A3527G } \\
\text { Glu/Gly }\end{array}$ & $\begin{array}{l}\text { G3528T } \\
\text { Glu/Asp }\end{array}$ & $\begin{array}{l}\text { C3699T } \\
\text { Thr/Thr }\end{array}$ & $\begin{array}{l}\text { T3803G } \\
\text { Phe/Cys }\end{array}$ & $\begin{array}{l}\text { T3813C } \\
\text { Thr/Thr }\end{array}$ & $\begin{array}{l}\text { A3817G } \\
\text { Arg/Gly }\end{array}$ & $\begin{array}{l}\text { G3868A } \\
\text { Cys/Tyr }\end{array}$ & $\begin{array}{l}\text { G3875A } \\
\text { Glu/Lys }\end{array}$ & $\begin{array}{l}\text { T4155C } \\
\text { Asn/Asn }\end{array}$ & $\begin{array}{l}\text { A4165C } \\
\text { Thr/Thr }\end{array}$ & $\begin{array}{c}\text { TTGATATTA } \\
3935 \text { to } 3943 \\
\text { Deletion } \\
\text { (lle+Asp+lle) }\end{array}$ \\
\hline 0 & 9 & 2 & 1 & 0 & 0 & 0 & 0 & 1 & 0 & 0 & 0 & 0 & 0 & 0 \\
\hline 1 & 10 & 3 & 0 & 0 & 1 & 1 & 0 & 0 & 0 & 0 & 0 & 0 & 1 & 0 \\
\hline 2 & 11 & 0 & 0 & 0 & 0 & 0 & 0 & 0 & 0 & 0 & 0 & 0 & 0 & 0 \\
\hline 3 & 11 & 2 & 0 & 0 & 0 & 0 & 0 & 0 & 0 & 0 & 0 & 1 & 0 & 1 \\
\hline 4 & 10 & 1 & 0 & 0 & 0 & 0 & 1 & 0 & 0 & 0 & 0 & 0 & 0 & 0 \\
\hline 5 & 13 & 1 & 0 & 0 & 0 & 0 & 0 & 0 & 1 & 0 & 0 & 0 & 0 & 0 \\
\hline 6 & 13 & 2 & 0 & 0 & 0 & 0 & 0 & 0 & 0 & 1 & 1 & 0 & 0 & 0 \\
\hline 7 & 12 & 0 & 0 & 0 & 0 & 0 & 0 & 0 & 0 & 0 & 0 & 0 & 0 & 0 \\
\hline 8 & 11 & 0 & 0 & 0 & 0 & 0 & 0 & 0 & 0 & 0 & 0 & 0 & 0 & 0 \\
\hline 9 & 12 & 1 & 0 & 1 & 0 & 0 & 0 & 0 & 0 & 0 & 0 & 0 & 0 & 0 \\
\hline
\end{tabular}
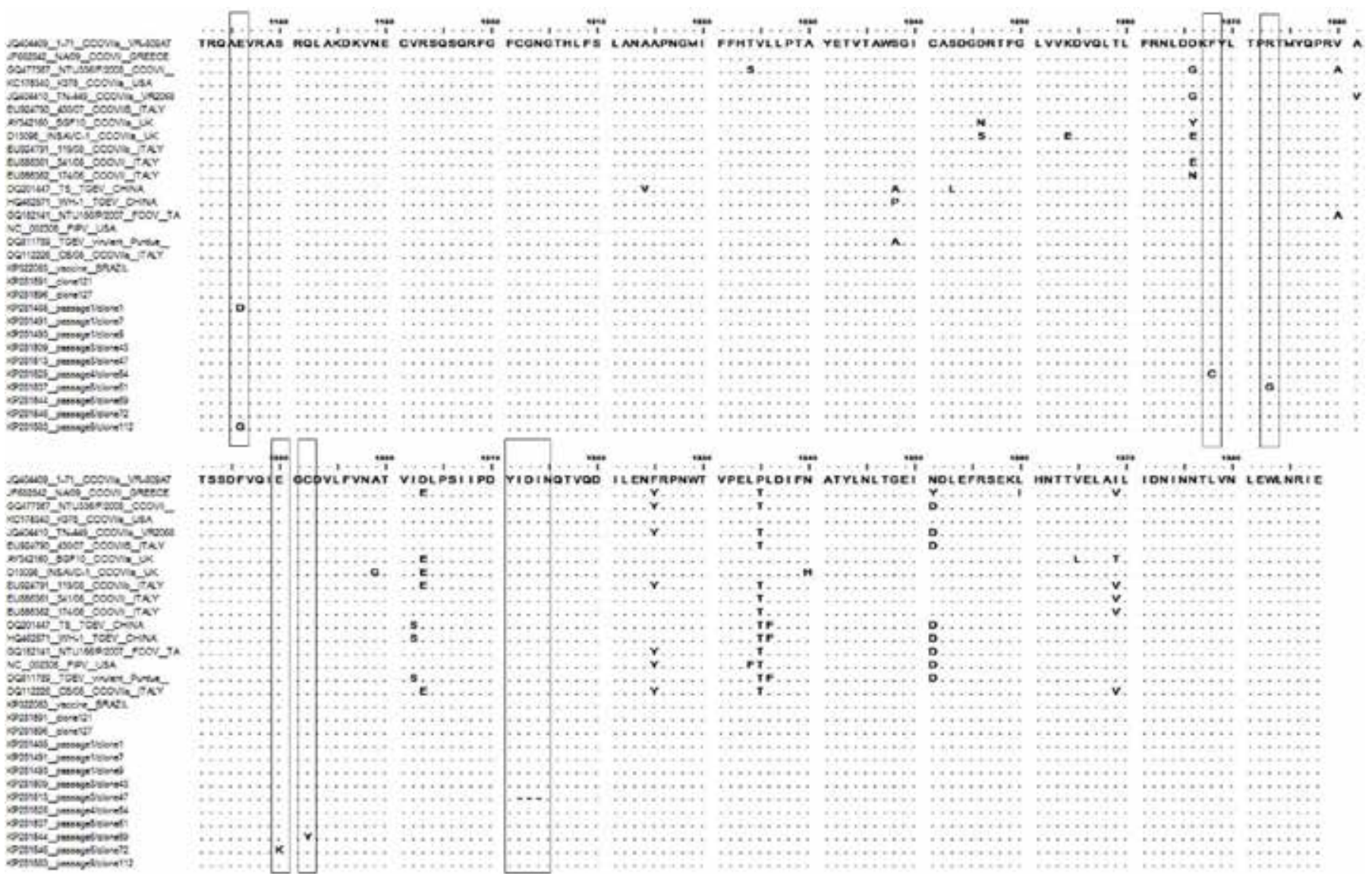

Figure 1 - Clones' sequences with amino acids mutations in Alphacoronavirus-1 S2 subunit (aa 1172 to 1388 in strain 1-71 Genbank JQ404409) after serial passages of strain 1-71 in A72 cells 


\section{Discussion}

After nine serial passages in A72 cells, the 1-71 vaccine strain of $\mathrm{CCoV}$ showed a low relative number of mutations when the clonal diversity of a segment of the S2 subunit was focused, without a passage-association pattern, which might indicate that this strain have reached a quite stable virus-cell relationship with no further mutations being fixed even after serial passages.

Though the region of the $S$ gene targeted in this study is responsible for membrane fusion and syncytial formation and has a higher mutation pressure than the S1 region, responsible for binding to cellular receptors (LAI; CAVANAGH, 1997), nucleotide polymorphism may also be found in S2 region (GALLAGHER; BUCHMEIER, 2001) allowing also virus entry into a variety of types of cells in trypsin-independent way (BELOUZARD et al., 2009; BORUCKI et al., 2013).

A study using a FIPV (Feline infectious peritonitis virus, a cat alphacoronavirus) strain passaged 100 times in A72 cells has shown that, from the original strain to the $8^{\text {th }}$ passage, amino acids substitutions occurred in S1 (T599A and $\mathrm{A} 743 \mathrm{~V}$ ), while in S2 an amino acid substitution occurred only at the $100^{\text {th }}$ passage (R1325E) (PHILLIPS et al., 2013).

TGEV (Transmissible gastroenteritis virus), another alphacoronavirus, has been shown to have a S585A in S1 at passage 50 in PK (Porcine Kidney) cells leading to attenuation of virulence (LI et al., 2010).

As seen in Table 1, the mutations detected amongst the passages were not fixed, which could be due either to genetic drift or to a bias on the randomness of the selection of clones for DNA sequencing.

Though these reports provide evidence that alphacoronaviruses are genetically quite stable after a high number of passages in cell cultures based on full-genome sequences, such sequences have been obtained for only one (LI et al., 2010) and four (PHILLIPS et al., 2013) passages and not in a serial mode and only the dominant sequence instead of the mutant spectrum has been assessed. As shown in the present study, assessing the clonal diversity of sequences, even based on a small section of a low polymorphic area such as $\mathrm{S} 2$, with sequences obtained for every passage, is paramount to remove biases from in vitro virus evolution studies.

Once the dominant strain is stable and adapted to a new host cell, adaptation is a rapid process (FANG et al., 2005) and thus the fixation of the Master Sequences in $\mathrm{CCoV}$ might have been a result of this stability mainly due to neutral evolution, as shown herein by the selection regime analysis.

In summary, cell-adapted CCoV-II vaccine strains may be highly genetically stable after serial passages in a same cell line, accumulating mainly synonymous nucleotide substitutions in the spike gene due to a stable cell-host relationship, with predictable low immunogenic variation.

\section{Conflict of Interest}

None

\section{Acknowledgments}

The work was supported by CNPq (grant \# 301225/20133), CAPES/PROEX (grant\# 3006/2011) and FAPESP (grant\#2010/19399-2) and approved by the Bioethics Commission of the School of Veterinary Medicine and Animal Science of the University of São Paulo (protocol number \# 2188/2011).

\section{References}

BELOUZARD, S.; CHU, V. C.; WHITTAKER, G. R. Activation of the SARS coronavirus spike protein via sequential proteolytic cleavage at two distinct sites. Proceedings of the National Academy of Sciences USA, v. 106, n. 14, p. 5871-5876, 2009. doi: 10.1073/ pnas.0809524106.

BORUCKI, M. K.; ALLEN, J. E.; CHEN-HARRIS, H.; ZEMLA, A.; VANIER, G.; MABERY, S.; TORRES, C.; HULLINGER, P.; SLEZAK, T. The role of viral population diversity in adaptation of bovine coronavirus to new host environments. PLoS One, v. 8, n 1, e52752, 2013. doi: 10.1371/journal.pone.0052752.

BOSCH, B. J.; VAN DER ZEE, R.; DE HAAN, C. A.; ROTTIER, P. J. The coronavirus spike protein is a class I virus fusion protein: structural and functional characterization of the fusion core complex. Journal of Virology, v. 77 , n. 16 , p. $8801-8811,2003$. doi: $10.1128 /$ JVI.77.16.8801-8811.2003. 
DE GROOT, R. J.; BAKER, S. C.; BARIC, R. S.; BROWN, C. S.; DROSTEN, C.; ENJUANES, L.; FOUCHIER, R. A.; GALIANO, M.; GORBALENYA, A. E.; MEMISH, Z. A.; PERLMAN, S.; POON, L. L.; SNIJDER, E. J.; STEPHENS, G. M.; WOO, P. C.;ZAKI, A. M.; ZAMBON, M.;ZIEBUHR, J. Middle East respiratory syndrome coronavirus (MERS$\mathrm{CoV}$ ): announcement of the Coronavirus Study Group. Journal of Virology, v. 87, n. 14, p. 7790-7792, 2013. doi: 10.1128/JVI.01244-13.

DECARO, N.; MARI, V.; CAMPOLO, M.; LORUSSO, A.; CAMERO, M.; ELIA, G.; MARTELLA, V.; CORDIOLI, P.; ENJUANES, L.; BUONAVOGLIA, C. Recombinant canine coronaviruses related to transmissible gastroenteritis virus of Swine are circulating in dogs. Journal of Virology, v. 83, n. 3, p. 1532-1537, 2009. doi: 10.1128/JVI.01937-08.

FANG, S. G.; SHEN S.; TAY, F. P.; LIU, D. X. Selection of and recombination between minor variants lead to the adaptation of an avian coronavirus to primate cells. Biochemical and Biophysical Research Communications, v. 336, n. 2, p. 417-423, 2005. doi: 10.1016/j.bbrc.2005.08.105.

GALLAGHER, T. M.; BUCHMEIER, M. J. Coronavirus spike proteins in viral entry and pathogenesis. Virology, v. 279, n. 2, p. 371-374, 2001. doi:10.1006/viro.2000.0757.

LAI, M. M.; CAVANAGH, D. The molecular biology of coronaviruses. Advances in Virus Research, v. 48, p 1-100, 1997.

LI, J. Q.; CHENG, J.; LAN, X.; LI, X. R.; LI, W.; YIN, X. P.; LI, B.Y.;YANG, B.; LI, Z. Y.; ZHANG, Y.; LIU, J. X. Complete genomic sequence of transmissible gastroenteritis virus TS and 3' end sequence characterization following cell culture. Virologica Sinica, v. 25, n. 3, p. 213-224, 2010. doi: 10.1007/s12250-010-3108-2.

MARTIN, D. P.; LEMEY, P.; LOTT, M.; MOULTON, V.; POSADA, D.; LEFEUVRE, P. RDP3: a flexible and fast computer program for analyzing recombination. Bioinformatics, v. 26, n. 19, p. 2462-2463, 2010. doi: 10.1093/bioinformatics/btq467.

MASTERS, P. S. The molecular biology of coronaviruses. Advances in Virus Research, v. 66, p. 193-292, 2006. doi: 0.1016/S0065-3527(06)66005-3.
MASTERS, P. S.; PERLMAN, S. Coronaviridae. In: KNIPE, D. M.; HOWLEY P. M. Field's Virololgy. 6. ed. Philadelphia: Lippincott Williams \& Wilkins, 2013. p. 825-858.

MUSE, S. V.; GAUT, B. S. A likelihood approach for comparing synonymous and nonsynonymous nucleotide substitution rates, with application to the chloroplast genome. Molecular Biology and Evolution, v. 11, n. 5, p. 715-724, 1994.

PHILLIPS, J. E.; HILT, D. A.; JACKWOOD, M. W. Comparative sequence analysis of full-length genome of FIPV at different tissue passage levels. Virus Genes, v. 47, n. 3, p. 490-497, 2013. doi: 10.1007/s11262-0130972-5.

POND, S. L.; FROST, S. D.; MUSE, S. V. Phy: hypothesis testing using phylogenies. Bioinformatics, v. 21, n. 5, p. 676-679, 2005. doi: 10.1093/bioinformatics/bti079.

PRATELLI, A. Genetic evolution of canine coronavirus and recent advances in prophylaxis. Veterinary Research, v. 37, n. 2, p. 191-200, 2006. doi: 10.1051/vetres:2005053.

PRATELLI, A. High-cell-passage canine coronavirus vaccine providing sterilising immunity. Journal of Small Animal Practice, v. 48 , n. 10, p. $574-578,2007$. doi: 10.1111/j.1748-5827.2007.00416.x.

PRATELLI, A.; DECARO, N.; TINELLI, A.; MARTELLA, V.; ELIA, G.; TEMPESTA, M.; CIRONE, F.; BUONAVOGLIA, C. Two genotypes of canine coronavirus simultaneously detected in the fecal samples of dogs with diarrhea. Journal of Clinical Microbiology, v. 42, n. 4, p. 1797-1799, 2004. doi: 10.1128/JCM.42.4.17971799.2004 .

TAMURA, K.; STECHER, G.; PETERSON, D.; FILIPSKI, A.; KUMAR, S. MEGA6: Molecular Evolutionary Genetics Analysis version 6.0. Molecular Biology and Evolution, v. 30, n. 12, p. 2725-2729, 2013. doi: 10.1093/molbev/mst197.

WERTHEIM, J. O.; CHU, D. K.; PEIRIS, J. S.; KOSAKOVSKY POND, S. L.; POON, L. L. A case for the ancient origin of coronaviruses. Journal of Virology, v. 87, n. 12, p. 7039-7045, 2013. doi: 10.1128/JVI.03273-12. 